Egyptian Journal of Archaeological and Restoration Studies
An international peer-reviewed journal published bi-annually
www.ejars.sohag-univ.edu.eg

Original article

\title{
REPRESENTATIONS OF HOMELESS CHILDREN IN WARLIKE SCENES IN THE NEO-ASSYRIAN PERIOD
}

\author{
Abdullah, F. \\ Egyptology dept., Faculty of Archaeology, Cairo Univ., Cairo, Egypt \\ E-mail address: drfawziahabdullah@gmail.com
}

\begin{tabular}{l}
\hline Article info. \\
\hline Article history: \\
Received: $19 / 9 / 2019$ \\
Accepted: $24 / 2 / 2020$ \\
Doi: $10.21608 /$ ejars.2020.98961 \\
\\
\\
Keywords: \\
Neo-Assyrian period \\
Children \\
Prisoners \\
Captives \\
Siege \\
Deportees \\
\hline
\end{tabular}

\begin{tabular}{l} 
EJARS - Vol. 10 (1) - June 2020: 43-57 \\
\hline Abstract: \\
The purpose of this study is to focus on how children were \\
graphically represented in warlike scenes, especially those who \\
accompanied captives and prisoners of war and those related to \\
the scenes of siege and exile in Mesopotamian art during the Neo- \\
Assyrian period (911-612 B.C.). The study discussed examples of \\
children's depictions in a warlike landscape in Neo-Assyrian art in \\
the First Millennium BC. The reason for choosing this topic is to \\
shed more light on the fact that homeless children are the most \\
suffering people from the woes of war. It is noteworthy that children \\
were generally represented less in the military and warlike scenes \\
than daily life and civilian scenes possibly due to the unparalleled \\
military expansion and superiority that characterized this time or \\
because of the Assyrian artists' concern to depict captives of all \\
ages to express their strength and superiority. The present study \\
did not investigate all the representations of people and children \\
who were taken as prisoners in the Neo-Assyrian period. Rather, \\
it indicated the familiar situations of children with captives and \\
prisoners in this period.
\end{tabular}

\section{Introduction}

Numerous studies have addressed the representation of childhood and motherhood in Mesopotamia. For example, Boudin, Rollin, and Mendelsohn focused on human motherhood or goddesses of childbirth and wifely. From the Neolithic period to the Neo-Assyrian period, the mother and the child were represented together in scenes, statutes, cylindrical seals, and terracotta [1-3]. According to Melville, Veenhof and Eidem, Al-Hashem, and others, textual pieces of evidence tell about the condition of children with their families and the social function of women from the royal text and several letters in the Neo-Assyrian period [4-9]. Children appeared in warlike scenes of the Neo-Assyrian period in the first millennium B.C., accompanying prisoners. They also appeared in warfare, siege, and exile views. Pieces of evidence of such repr- esentation in the third and second millennia B.C. are still absent. It can be assumed that Assyrians wanted to express their political power by demonstrating the processions of their captives. They achieved their glorious control and outstanding military aggression from the beginning of the Neo-Assyrian period as their empire expanded to include most parts of the ancient near east [10-14]. This military superiority was reflected in their arts, especially in the implementation of sculptures, paintings, and inscriptions that decorated Assyrian palaces and temples. The arts were slightly influenced by the artistic styles of craftsmen who were brought from neighboring countries occupied by the Assyrians [10]. Several studies adderssed the enemies of the Neo-Assyrian period, such as Collins and Mohamed [15,16]. Assyrians meant by representing and disp- 
laying the processions of their captives and tribute payers of different countries to show their strength and superiority [15, 16]. In most cases, the Assyrian art tried hard to depict the features of faces and clothes of their enemies [16] to indicate their origins or roots. According to Albenda, some of the prisoners and captives appeared naked in scenes from the reign of Shalmaneser III (859-842 B.C.) and Sargon II (722-705 B.C.) [17]. Parker and Poo reported that the Assyrian attitude to captives was aggressive and cruel, showing the oral message of their power to others $[18,19]$. Some studies, e.g. Saleh and Abdullatif, examined the scenes of fighting and war generally and depicting the siege and the captive's processions or their positions compared with other contemporary civilizations [20,21]. Most of the other studies are interested in the Neo-Assyrian period, showing the textual and graphical evidence related to the Assyrian war and their captives, without focusing on portraying children, in particular [10,15-17]. The present study presents not only a survey of some graphical representation of children within warlike scenes but rather aims to highlight children's positions with prisoners of wars and captives as an important category of them within the timeframe of the study. It is noticeable that two terms are used commonly in this study, namely prisoners and captives. According to Oates, and Oates; Saggs, and Zaccagnini, these terms shared the same meaning in the Assyrian texts. They denoted the civilians who lost their freedom by the occupation of the Assyrians and became prisoners [22-24]. The present study uses the word captive to signify the loss of freedom by imprisonment. Therefore, the word prisoner comes next stage after the captivity. The third term used is deportees that mean people whose land was usurped by the Assyrians. Thus, they were deported outside their home.

\section{Methodological Study}

\subsection{The Assyrian policy of deporting their enemies and its reflection on deported children}

One of the most important ways used by the Assyrians to dispossess the throne of their enemy was to move them away from their homelands $[25,26]$. According to ElSaady and Haugberg, this phenomenon of deportation was achieved by many empires in the ancient near east, such as the Egyptian, Assyrian, and Babylonian [27,28]. Shahylat and Al-Hamadani and Oded argued that this strategy was well-known in the middle Assyrian period [29,30]. Tsakanyan reported that the first Assyrian king who practiced this policy widely was TiglathPileser III (745-724 B.C.) [31]. He not only moved the people of Damascus and Samaria from their homelands but also resettled the Arabs instead in Samaria. The textual sources of his reign indicated the deportation of approximately eighty-seven hundred and fifty people described by texts as Assyrian people [32]. Moreover, Beckman and Salman argued that the Judeans of Samaria were the most people who suffered from dispossession by Assyrians [26,33]. The deportation of captives and sending them away to other cities were frequently depicted in Assyrian art [15]. The successors of TiglathPileser III, such as king Sargon II (722705 B.C.), adopted his policy [34-36]. AlAaraji and Al-Qaabi and Sarlo analysed the political and economic causes of this policy $[37,38]$. Politically, the Assyrians wanted to punish the rebel nations and weaken the center of resistance by deporting the important ethnic groups away from their homeland. It targeted senior officials and skilled craftsmen [37]. The most important economic reason was using the deportees as farmers or as soldiers [38]. The conditions of the deportee's families and their children have naturally been greatly affected by this policy. According to Saggs, [24] the letters from the record of the reign of Tiglath-Pileser III from Nimrud (ND2634) referred to the problem of feeding captured peoples who were deported from their homes after the war. One of his officials, named AshurShallimanni, wrote a letter to draw attention to the need for grain and oil to feed six thousand prisoners of war to survive and recover [24]. Nadali analyzed some Assyrian documents and sources of the second half of the $7^{\text {th }}$ century B.C. on feeding the people of Baqarru, which may be a settlement 
where captives were collected. Baqarru letters were written over a long time of Sargon II [39]. Nadali reported that deportees were treated as a part of the booty and as goods among the Assyrian officials and soldiers. Both written and visual sources referred to the citizens of conquered territories as prisoners of war and sometimes as employed in Assyrian administrative works [39]. Zaccagnini examined other texts of Emar famine that happened after the siege of the Syrian town at Emar during the Ashurbanipal's siege of Babylonia. These remarkable texts showed that war forced people to sell their children to eat. The nine Nippur tablets explained how parents used to sympathize with Assyrian soldiers to sell their daughters or sons. One of the Assyrian letters told by a mother reads "My husband went away, my/our children were all babies and I did not have anyone who could feed them, therefore I have sold my daughter....and (thus) I could feed the (other) small children during the year of famine."[23]

\subsection{Examples of children represe- ntations in warlike scenes in the Neo-Assyrian period (911-612 B.C.)}

This section discusses some examples of the prisoners and deportees' scenes. It shows the most important situations of the children accompanying these scenes. The scenes were arranged according to the chronological order of the Assyrian kings in the Neo-Assyrian period.

2.2.1. A nude child among prisoners of war -the Bronze Gate of Balawatthe reign of Shalmaneser III (726722 B.C.)

The victories of Shalmaneser III were represented on the bronze reliefs that decorated the wooden gates of a palace or a temple in Balawat, near modern Mosul, not far from the source of the Tigris [40]. One of these depictions shows a slow procession of women dressed in long garments, naked men, and one nude child. They were driven by an Assyrian soldier, fig. (1).

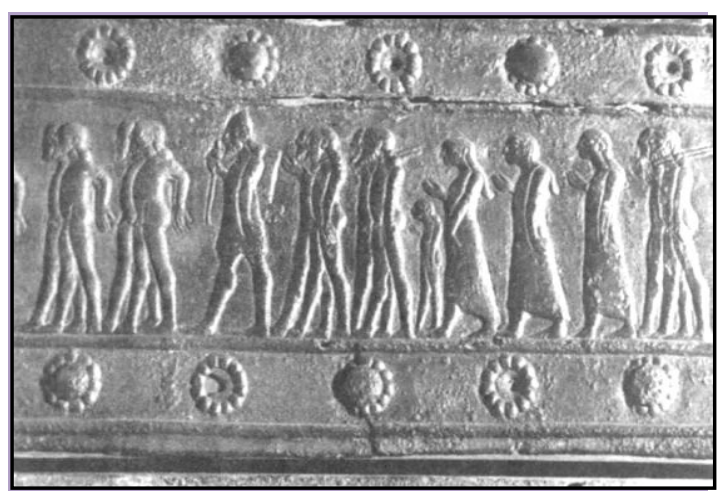

Figure (1) Shows a nude child among prisoners of war -The Bronze Gate of Balawat the reign of Shalmaneser III (726-722 B.C.), (after Bahrani, 1993).

According to Bahrani [41] the concept of nudity in Mesopotamian art generally expressed fertility, death, and defeat. In the NeoAssyrian period (883-612 B.C.), nudity in many representations of the male prisoners of war was shown when they were executed by impalement, decapitation, or fall in combat. Bahrani argued that the women and children were kept as slaves after war, and they were never treated in the same manner as the yoked nude male [41]. Albenda [17] discussed some examples of nude deportees and captives. She referred to the long rows of prisoners taken from Lachish after the successful campaign of king Sennacherib. Two nude male figures were stretched and lied on the ground for the act of flying, by the team of Assyrian soldiers. This scene was repeated on the relief of Sargon II [17]. As for the nudity of children in Mesopotamian art, there are two possibilities for explaining this depiction. First, it was a traditional sign of childhood, such as nudity representations in the ancient near east. In Egypt, for example, children [42] were depicted playing outdoor or with their parents. Egyptian art continued to represent children without clothes before they reached puberty or slightly beyond [43]. In addition, the children captives in ancient Egypt were almost represented naked [44]. Second, the nudity of some captives of children in this article refers to the same meaning of psychological oppression and humiliation as the manner of captives' men. This assumption is supported by a nude child, fig. (1) whose head was represented down. 
Maybe, he felt ashamed because of his male relatives who were stripped of their clothes, marching in front of him. Many nude children are shown in the following examples.

2.2.2. Cruel treatment of Arab children and women -the reign of TiglathPileser III (745-724 B.C.)

The annals and inscriptions of TiglathPileser III reported his campaigns to the Arabian Peninsula $[45,46]$. One of these inscriptions indicates the cruelty of the Assyrians in treating Arab women and children captives. It depicts an Assyrian warrior dragging an Arab woman (perhaps a queen). In the back, another woman is carrying a little child over her shoulder and catching another one [47], fig. (2).

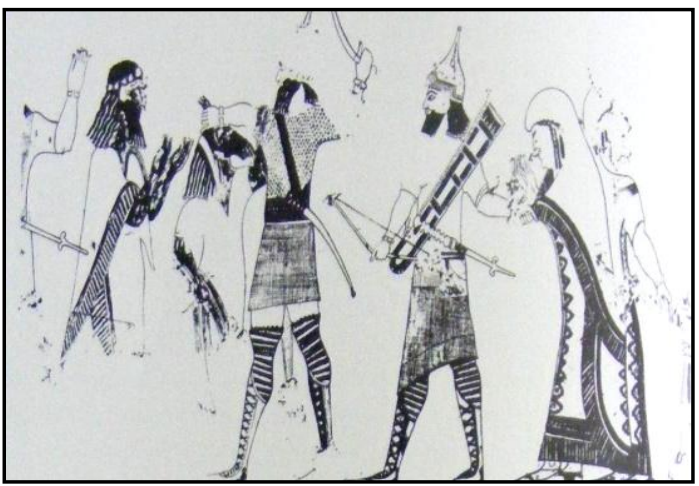

Figure (2) Shows cruel treating of Arab childrenThe reign of Tiglath-Pileser III (745-724 B.C.) (after Reade, 1998)

2.2.3. Sending away Medes children on bullock carts -the reign of TiglathPileser III (745-724 B.C.)

This scene was originally from room (15) in the central palace of Tiglath-Pileser III in Nimrud (ancient Kalhu). It was an alabaster wall panel relief, divided into three registers. It depicts Medes deportees' groups who were deported from their homeland. The third register illustrates two bullock carts. Each cart carries two women and a little child, fig. (3-a,b). The captives are shown with their cattle moving toward the same direction. It is noticed that deportees were counted like their cattle by Assyrian scribes. This panel is displayed in the British Museum in London $[25,48,49]$.
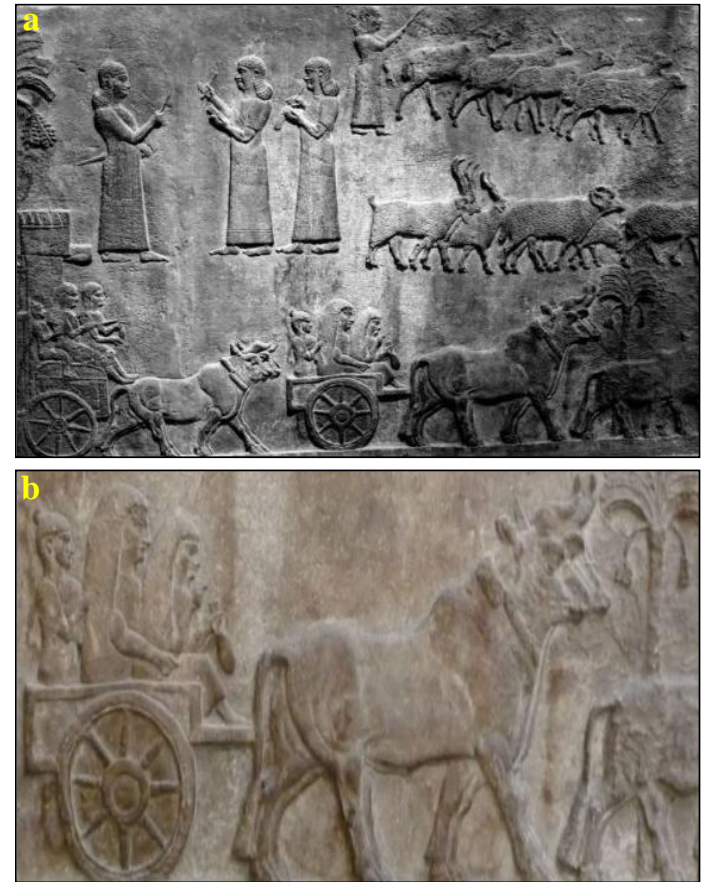

Figure (3) Shows ‥ . sending away Medes children on bullock carts; the reign of Tiglathpileser III (745-724 B.C.) (after Ataç, 2010), b. details of the figure (after Reade, 1983)

2.2.4. A walking child and carrying baby suffering the post -war tragedy- the reign of Tiglath-Pileser III (745-724 B.C.)

This scene was also originally from the palace of Tiglath-Pileser III at Nimrud (ancient Kalhu). It represents a group of prisoners of war waiting for their doom after the occupation of their city. On the left-hand side of the scene, a palm tree has been pulled up from its roots to symbolize the Assyrian policy of destruction of the economic infrastructure of the place and achieving scorched policy of earth. This phenomenon of deportation was carried out by many empires in the ancient near east through ancient history, e.g. the Egyptian, Assyrian, and Babylonian. On the righthand side, the king is sitting under his canopy and surrounded by his followers. On the left-hand side, a little naked boy walks with his father. The later carries his belongings on his shoulders. To his right, an exhausted woman was sitting on the ground. She was carrying her baby on her chest. Some women were depicted putting dirt on their heads to express the deep grief of losing their homes, fig. (4) $[27,50]$. 


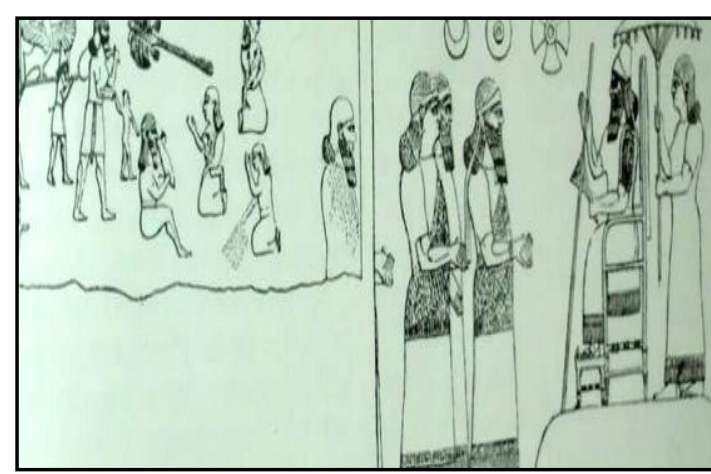

Figure (4) Shows a walking child and carrying baby suffering the post-war tragedy the reign of Tiglath-Pileser III (745-724 B.C.), (after Orthmann, 1975)

2.2.5. Children walking and riding-after the battle of Lachish-Sennacherib's reign (705-681 B.C.)

Lachish was one of the important campaigns in the reign of Sennacherib (705-681 B.C.). It took place in 701 B.C. in (Tell ed-Duweir or Tell Lachish) to the south of Palestine, map (1). The inscriptions in Hebrew on pottery pieces found in Tell-ed-Duweir indicated that this area was the city of Lachish, which Sen- nacherib seized [51]. The details of the battle were depicted originally on the walls of his southwest palace in Nineveh [50]. One of the scenes shows a great procession of Assyrian soldiers leading deportees after the battle through grapevines and oak trees in the countryside with the river. It shows children walking or riding with their captured families. Two women and a little child are carried on a bullock cart, while another child is walking between two men in the second row [52,53], fig. (5-a,b,c). The artists succeeded to simulate the structure of the place and the surrounding palms and trees [54]. Within these processions are shown two naked stretched men who were killed by Assyrian soldiers, fig. (5-a). These panels are now displayed in the British Museum in London [55]. The following scene depicts a captured enemy carrying a child on his shoulders, and the boy holds the head of his father. In front of them, two women are riding a donkey, fig. $(5-d, e)[15,56]$.

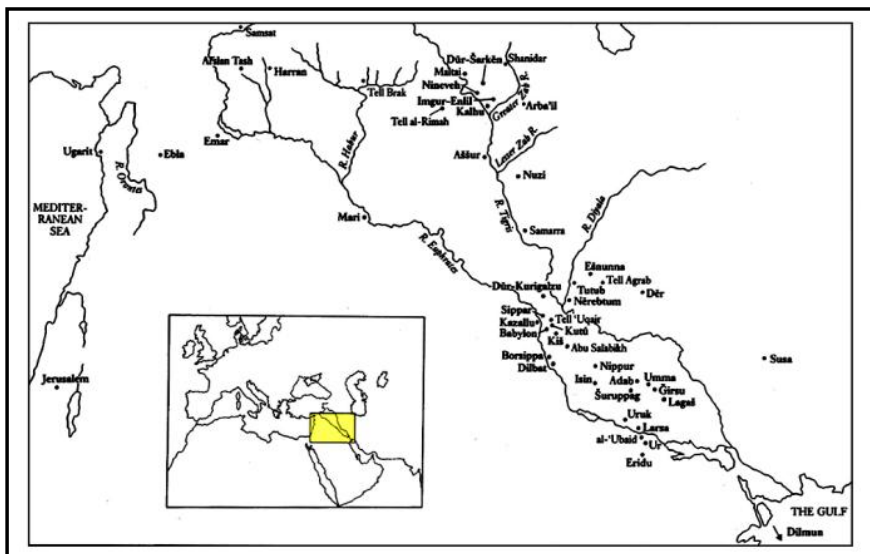

Map (1) Ancient sites in Mesopotamia (dkhlak.com/ about-assyria-and-empire/)

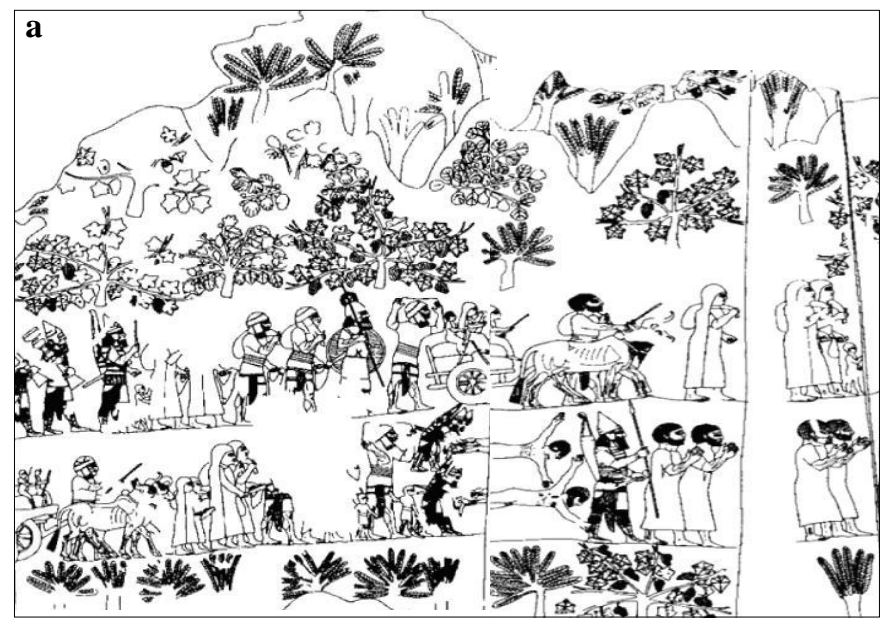



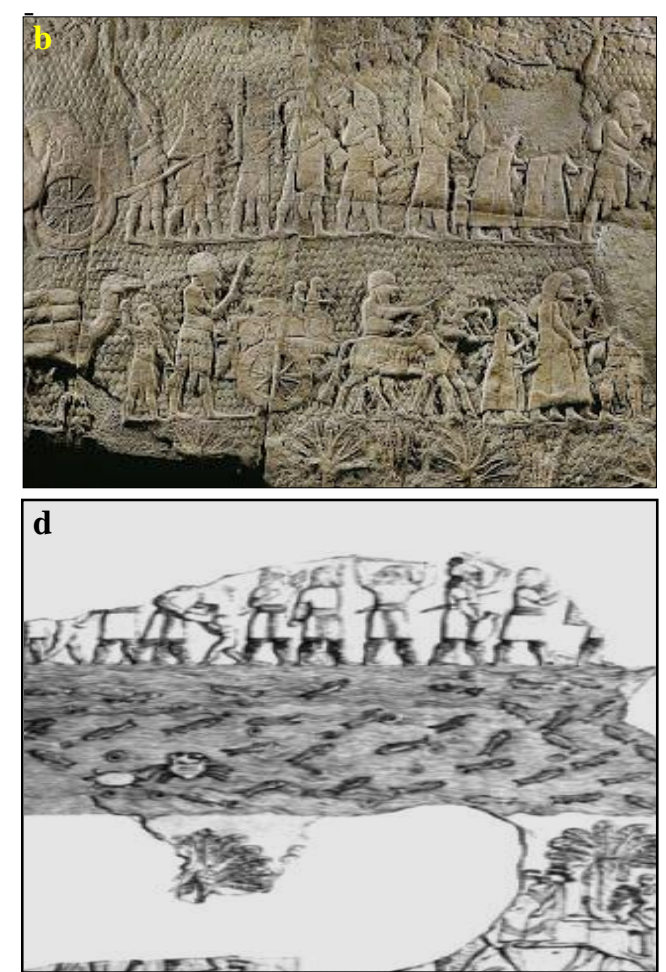
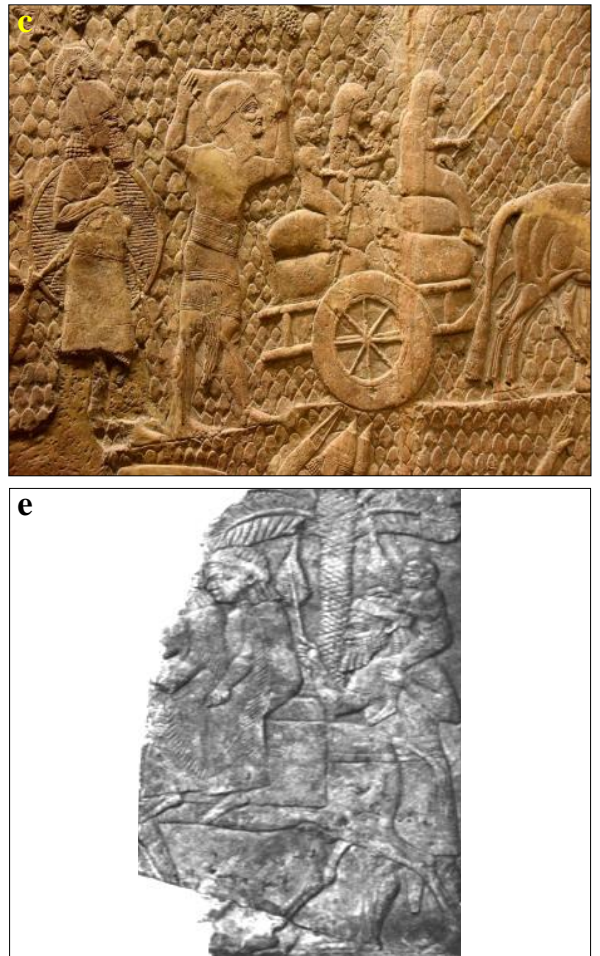

Figure (5) Shows children walking and riding the battle of Lachish; $\underline{\mathbf{a}}$. child is walking between two men

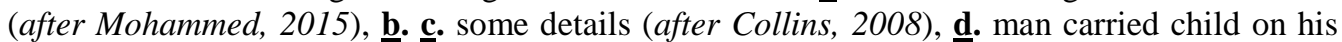
shoulders, e. details of fig. $\overline{5}-\bar{d}$ (after Porada, 1989)

\subsubsection{Child walking and drinking among Babylonian deported - Sennache- rib's reign (705-681 B.C.)}

A wall panel relief from the reign of Sennacherib originally from the southwest palace in Nineveh shows Babylonian deportees after the Assyrian occupation. A woman bents over a thirsty child to give him water from a bottle in her hand. The artists paid attention to details of the scenes of the palm trees, fig. (6). The panel is on display in the British Museum in London $[55,56]$. This scene can attest to the suffering of the children while being transferred from their home to another place.

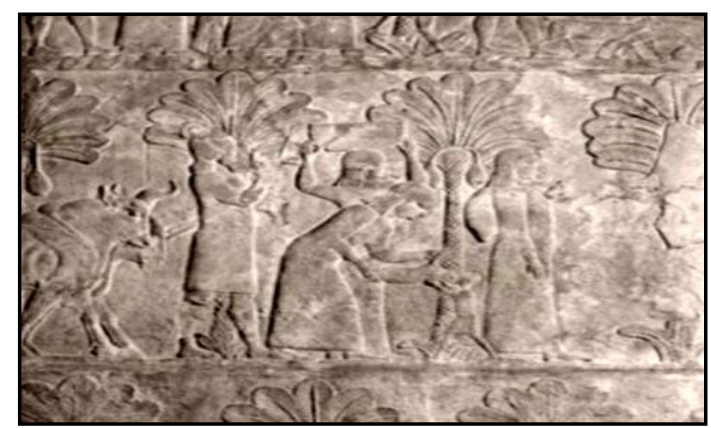

Figure (6) Shows Babylonian deported children walking and drinking- Sennacherib's reign (705-681 B.C.) (after Moortgat, 1975)
2.2.7. Elamite children walking after the Till Tuba campaign southwest of Iran-Ashurbanipal's reign (667629 B.C.)

The king's victory over the Elamite army was represented originally on the thirtysecond room of the southwest palace in Nineveh. According to Moortgat, this palace was constructed by Sennacherib, but it was completed in the reign of Ashurbanipal (667-629 B.C.) [56]. A wonderful landscape of the battle of Till-Tube on the river of Ulai, southwest of Iran depicted the events of this campaign, map (2). In the upper rows of the scene, children walk side by side with the processions of Elamite captives, fig. (7-a,b). All children in the two rows wear clothes, but two of them are naked. Children were mostly dressed up, except in cases in which they appeared naked, fig. $g_{s}(1$, $4,5-a, b, c, d, e)$. This panel is on display in the British Museum [56,57], fig. (7-b). 


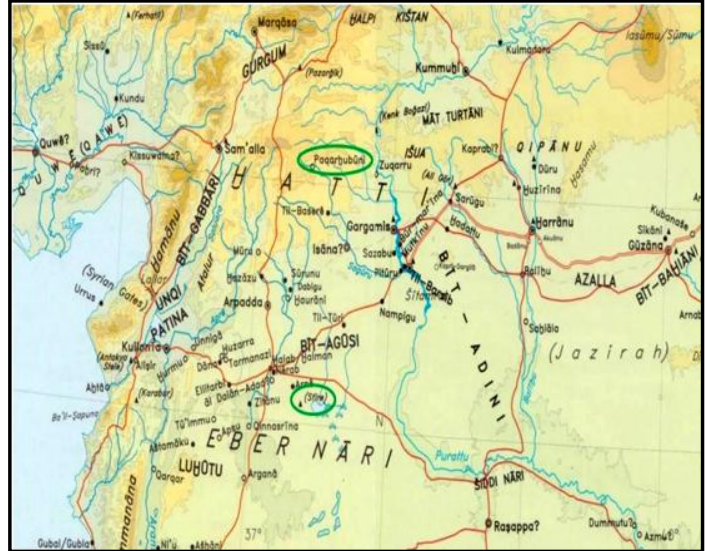

Map (2) Important ancient sites in Iran, (PM Thesis_display_NA_East.pdf)
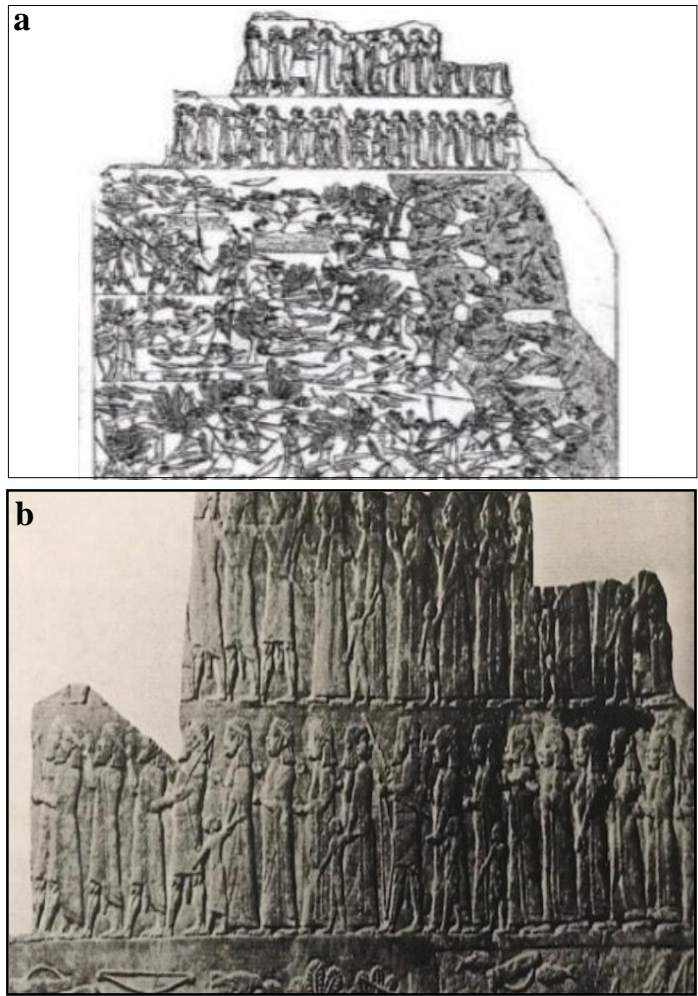

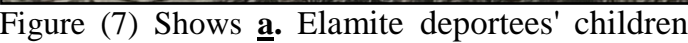
walking - (after Lebmann, Tallis, et al., 2019), b. details of upper rows of 7-a (after Moortgat 1975)

\subsubsection{Children walking with Elamite deported - Ashurbanipal's reign (667-629 B.C.)}

Another scene from the same place depicts the Assyrian campaign against Elamite. It shows king Ashurbanipal in his chariot overseeing the deportation of Elamites sent out from Susa. It shows a cart carrying two women [58]. In the middle row, an Assyrian pushes two prisoners in front, and a small child holds the hand of a man who may be his father, fig. (8-a,b) [59]. The captives wear long clothes and headbands, while the child is naked [59]. Cifarelli [60] thought that the nudity of war's prisoners is a tradition in Mesopotamian art. He assumed that this artistic phenomenon appeared in the art of Sumer and Akkad in the mid-third millennium B.C. Nudity in all Mesopotamian periods indicated death and mourning fig. (5-a). According to Cifarelli, the nudity of living prisoners is a type of psychological humiliation. Prisoners were stripped of their clothes, weapons, and possessions, fig. (1) [60]. This relief is on display in the Louvre Museum [59].

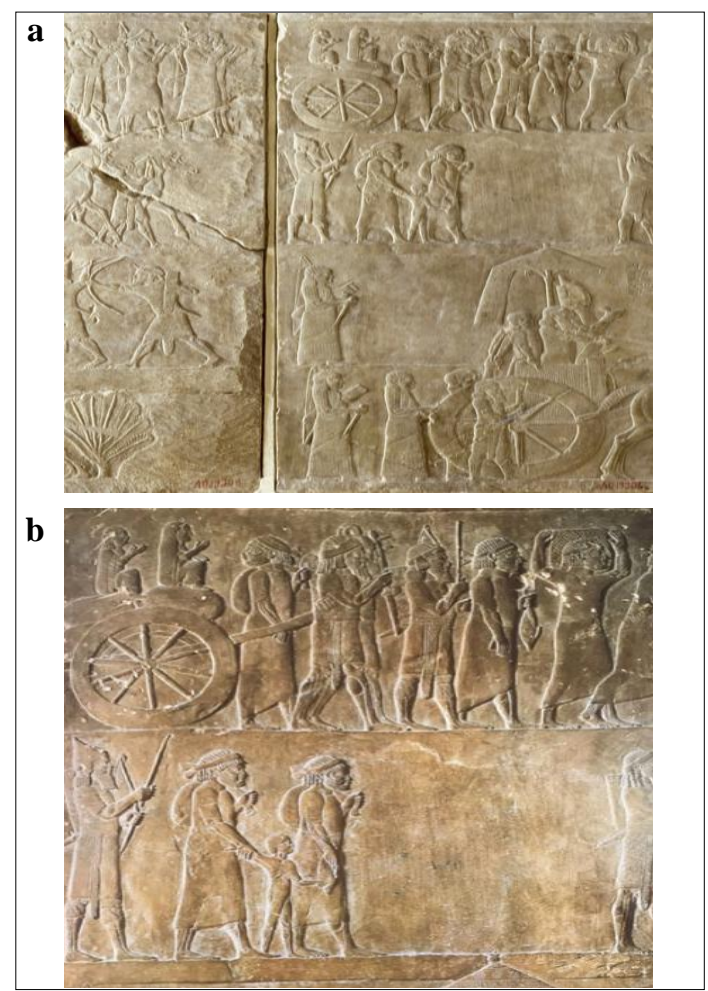

Figure (8) Shows a. King Ashurbanipal in his chariot oversees, $\underline{\mathbf{b}}$. details of fig. 8-a deportation of Elamite (after Matthiae 1999)

\subsubsection{Elamite infants and toddlers were deportees from Hamanu - Assur- banipal's reign (667-629 B.C.).}

Hamanu was a royal city of Elam in the Assyrian annals. The siege of Hamanu was represented originally in the northern palace of Assurbanipal at Nineveh. The group of Elamite prisoners was shown twice in the northern palace in the room (S, M) $[61,62]$. The Elamites deportees are represented carrying their children and belongings. Two 
women are breastfeeding their infants while walking. In the back two men appear. One of them is carrying his son on his shoulders, the other turns his head towards the Assyrian soldier who pushes him forward and holds a stick, fig. (9). In this engraving, the artist hardly showed the hands of men while carrying bags over their shoulders [15].

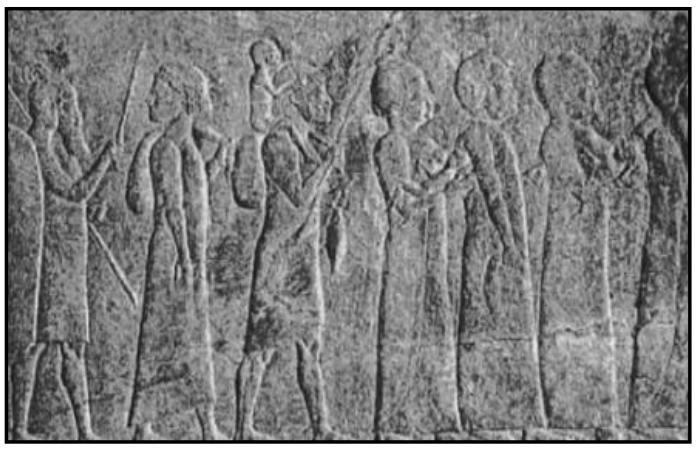

Figure (9) Shows Elamite infants and toddlers were deportees from Hamanu Assurbanipal's reign (667-629B.C.) (after Mohammed 2015).

2.2.10. Cruel treatment of Elamite children and women - Assurbanipal's reign (667-629 B.C.)

In the throne room of Ashurbanipal in the northwest palace at Nimrud (Kalkhu), a row of three women and a nude child were driven by an Assyrian soldier with strongly pushes. Some cattle were moving in the same direction, fig. (10). This panel is on display in the British Museum in London [49]. It shows that the women wear long garments, and everyone raises one or two hands to her head to express sadness and lamentation. It the same expression of sadness of women on the situation of death and the Egyptian funerary art [63].

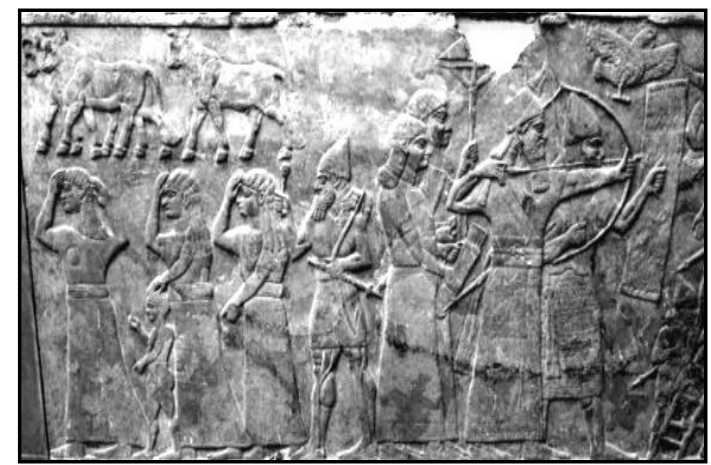

Figure (10) Shows cruel treatment of Elamite children and women Assurbanipal's reign (667-629B.C.) (after Araç, 2010).
2.2.11. A child descends to a boat during a siege of Elamite city - Assurbanipal's reign (667-629 B.C.).

A siege of Bit-Bunakki (one of the conquered Elamite cities) is represented originally in room $(\mathrm{G})$ of the North palace at Nineveh. It is now in the Vatican Museum, fig. (11). This city was situated on a river in the Rashi mountain region, where the border of Assyria was close. It represented the actual moment of the siege of Bit-Bunakki [62]. The nature of the location is depicted with a realistic scene of a river and boats transporting Elamites prisoners. It can be noticed that an Elamite child descends to a boat. He is helped by a lady [62].

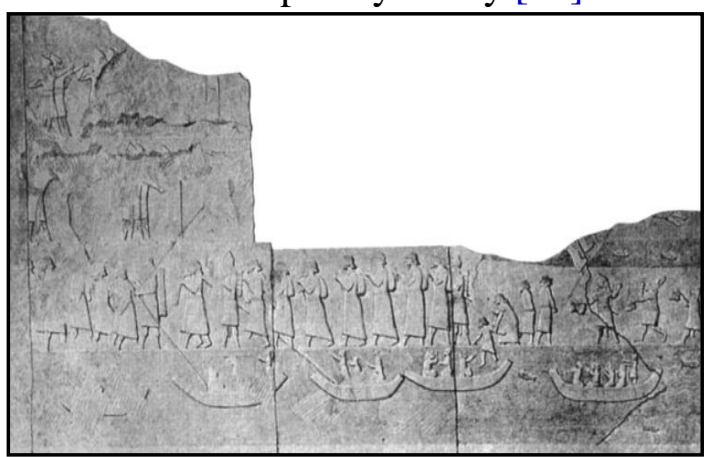

Figure (11) Shows a child descends to a boat during a siege of Elamite city Assurbanipal's reign (667-629 B.C.) (after Nadali, 2007).

2.2.12. An Egyptian child on dad's shoulders during the siege of an Egyptian city - Assurbanipal's reign (667-629 B.C.)

According to Spalinger and Kan, [63,64] Assyrians tried to conquer Egypt several times during the Neo-Assyrian period. The struggle between them continued with several Assyrian military campaigns and many Egyptian revolutions. The Assyrian siege of an Egyptian city was originally represented on limestone relief in the northern palace of Nineveh, ancient Tell Kouyunjik North Iraq, map (1). It is now displayed in the British Museum [63,64]. Matthiae reports that the upper row of the scene depicts Assyrians trying to assault the city using three ladders. He argues that this city may be Thebes or Memphite [59]. In the middle register, Egyptian prisoners are depicted at the moment of being taken 
by Assyrians, fig. (12-a,b) [59]. Moreover, a child is carried on dad's shoulders. Thus, a part of the father's body is hidden behind the child's leg, figs. (5-e, 12-b). It is worth noting that the physical features of Egyptian captives are depicted clearly. The Assyrian artist succeeded to represent the nature of the marine creatures in the Nile river on the edge of the scene.

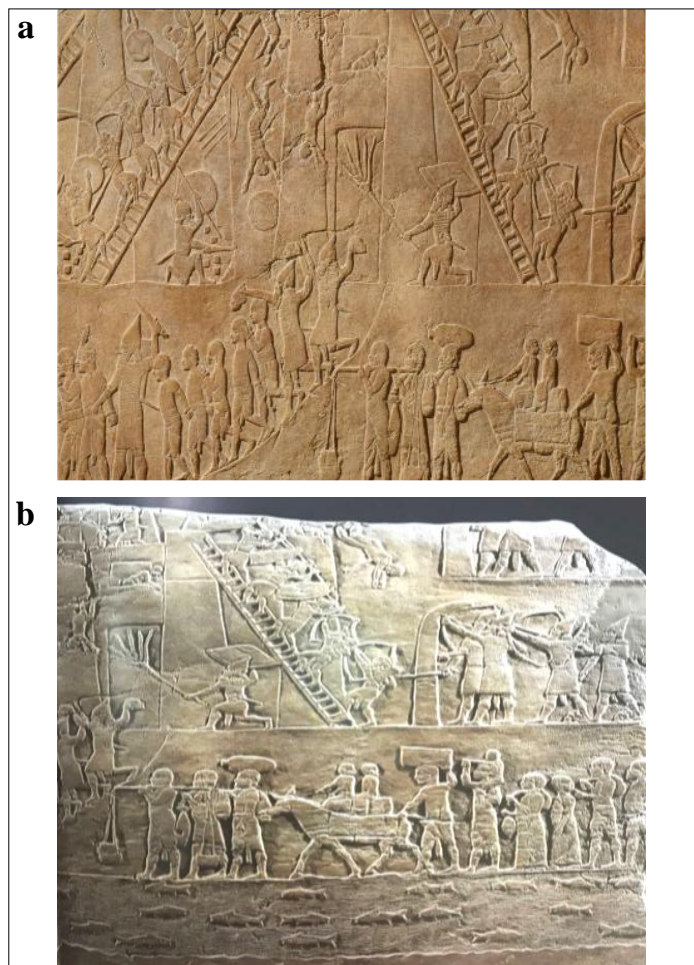

Figure (12) Shows a. Egyptian deportees: A child on dad's shoulders during the siege of an Egyptian city- Assurbanipal's reign (dreamstime.com/London-united-kingdom assy.-clay-tablet.), $\underline{\mathbf{b}}$. detail of details of fig. 12-a (after Matthiae 1999)

2.2.13. Prisoner children receiving meals after the war of the Syrian city of "Emar" - Assurbanipal's reign (667-629 B.C.)

In spite of the curly Assyrian treatment of their captives, some scenes show the Assyrians feeding prisoners after wars. According to Matthiae, [59] one of these scenes was found originally on rooms $(\mathrm{T}, \mathrm{V})$ in the northern palace of Nineveh, ancient Tell Kouyunjik of Assurbanipal, fig. (13). They are shown offering meals to a group of people of Emar accompanying children. A woman bents over a thirsty child to give him water from a bottle in her hand [59,65]. Adamthwaite, Hallo, and Goetze [66-68] thought that the texts of Emar (modern Tell Meskene-Qadime) proved that it was fallen under the Hittite rule during the Late Bronze Age. Emar is located in the north of Syria and was cited as a great city-stop on the way to Aleppo and Qatna in the west, map (1) [66-68]. Yamada discussed the Assyrian military against Emar, as a Hittitian city, in the reign of Tukulti-Ninurta $\mathrm{I}$ in the Middle Assyrian Period. Yamada called their citizens (Emaro-Hittites) people [69]. Nadali and Zaccagnini examined the texts of war and famine in Emar during the NeoAssyrian period, especially in Assurbanipal's siege, and its terrible effect on the prisoners. Some prisoners had to sell their children to feed the rest of their children $[22,23,39]$.

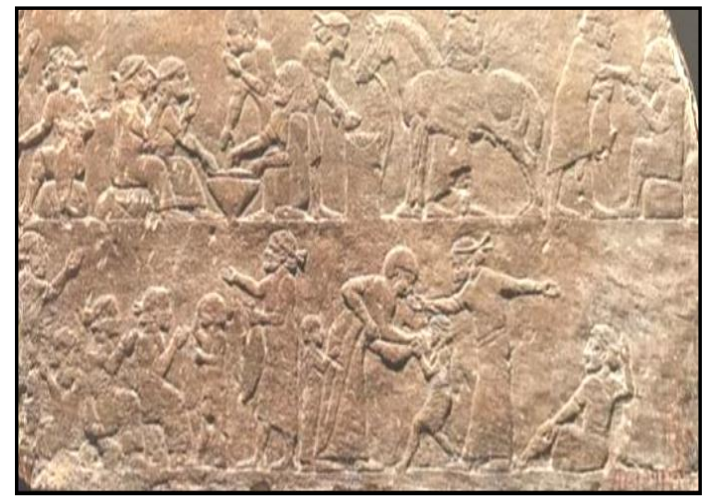

Figure (13) Shows prisoner children receiving meals after the war of the Syrian city of "Emar" Assurbanipal's reign (667-629B.C.) (after Matthiae 1999)

\section{Results}

The aforementioned scenes illustrate the graphical representation of children in the Neo-Assyrian period in the following situations, table (1): a) An infant is breastfed by his mother, fig (9). b) The toddlers are carried on the shoulders of one of the parents. They are still unable to walk or they can hardly walk few steps. Therefore, they are carried on the father's shoulders or the mother's chest, fig (4, 5-c,e, 9, 12 a,b). c) Children are riding a donkey or a bullock cart with mothers, fig (3-a,b, 5-a, b,c, 12-a,b). d) Children are walking, fig $(1,2,4,5-a, b, d, e, 6,7-a, b$ 8-a,b) in most of the studied scenes. Children are represented 
under ten before puberty. e) Children are taken among the detained prisoners and provided meals similar to the adult prisoners, fig (13). f) Children are given water by a woman as a realistic depiction to show the suffering while they are being transferred from their home to another place, fig $(6,13)$. g) A child is descending a boat during his departure from home, fig (11).

Table (1) the most important positions of children in warlike scenes in the Neo-Assyrian period

\begin{tabular}{|c|c|c|c|}
\hline No. & Positions & Date & Figures \\
\hline 1 & An infant is breastfed by his mother & $\begin{array}{l}\text { Assurbanipal's reign } \\
\text { (667-629B.C.). }\end{array}$ & 9 \\
\hline 2 & A toddler is carried on the shoulders. & $\begin{array}{l}\text { Sennacherib's reign } \\
\text { (705-681 B.C.) } \\
\text { Assurbanipal's reign } \\
\text { (667-629B.C.) }\end{array}$ & $4,5-c, e, 9,12-a b$ \\
\hline 3 & $\begin{array}{l}\text { A child is riding a donkey or a bullock } \\
\text { cart with his mother. }\end{array}$ & $\begin{array}{c}\text { Tiglath-Pileser III's reign } \\
\text { (745-724 B.C.) } \\
\text { Sennacherib's reign } \\
\text { (705-681 B.C.) } \\
\text { Assurbanipal's reign } \\
\text { (667-629B.C.) }\end{array}$ & $\begin{array}{c}3-a, b, 5-a, b, c, 12- \\
\text { a,b }\end{array}$ \\
\hline 4 & A child is walking. & $\begin{array}{c}\text { Tiglath-Pileser III's reign } \\
\text { (745-724 B.C.) } \\
\text { Sennacherib's reign } \\
\text { (705-681 B.C.) }\end{array}$ & $\begin{array}{l}1,2,4,5-a, b, d, e \\
6,7-a, b, 8-a, b\end{array}$ \\
\hline 5 & $\begin{array}{l}\text { Children are taken among the detained } \\
\text { prisoners and provided meals. }\end{array}$ & $\begin{array}{l}\text { Assurbanipal's reign } \\
(667-629 B . C .)\end{array}$ & 13 \\
\hline 6 & A child is given water by a woman. & $\begin{array}{l}\text { Sennacherib's reign } \\
(705-681 \text { B.C.) }\end{array}$ & 6,13 \\
\hline 7 & $\begin{array}{l}\text { A child is descending a boat during his } \\
\text { departure from home }\end{array}$ & $\begin{array}{l}\text { Assurbanipal's reign } \\
\quad(667-629 B . C .)\end{array}$ & 11 \\
\hline
\end{tabular}

\section{Discussion}

Some Assyrian sources described how kings cruelly treated the prisoners of war, such as skinning them alive to death $[58,70]$. They frequently used this method against antagonists who opposed the authority and struggled all the way through. Exile punishment was mostly applied against those who showed a lesser degree of defiance against the Assyrian authorities or showed surrender. The captive's family was taken into captivity and his personal properties were confiscated. Even the personal properties were taken away to be divided as a booty between Assyrian rulers and soldiers; this in fact affected the social status of the children and deprived them of freedom [70, 71]. The Assyrian policy of deportation naturally affected the conditions of the deportee's families and their children. Sometimes, the food was not enough for all deportees. According to Saggs, the records of the reign of Tiglath-Pileser III from Nimrud (ND 2634) referred to the problem of feeding captured peoples who were deported from their homes after the war. One of his officials named Ashur-Shallimanni wrote a letter to draw attention to the need for grain and oil to feed 6000 prisoners of war to survive and recover [24]. Despite the continued application of the exile and deportation policy against the prisoners of war during the Neo-Assyrian period, it seems that they received some health care, perhaps for practical purposes not for humanitarian reasons. It can be concluded that Assyrian care of their prisoners of war and captives was to keep them in good health to involve them in construction work and use them as skilled craftsmen or as farmers to achieve econ- 
omic prosperity [72]. The texts from the reigns of "Samsu-iluna" (1750-1712 B.C.) and "Hamurabi" (1728- 1712 B.C.) supported this idea. Both kings mentioned in their texts that they offered various kinds of meals for prisoners of war including meat, bread, and dates. This indicates that children who received the meals are also among the captives [59,70,73,74]. In other words, the care for deportees and prisoners of war in all ages, including children, was because of their economic value not for humanitarian reasons [68]. The textual evidence of famine after Ashurbanipal's siege of Syrian town at Emar showed parents selling their children to buy food $[22,23]$. The phenomenon of selling a family member began in the Old Babylonian Period in the second half of the second millennium B.C. It happened because of taxation and dry farming areas which led to famine. Emar documents and Assyrian texts illustrated the sum of payment (the prices) for the people being sold [22-24].

\section{Conclusions}

The present study concludes, the following points: *) In Mesopotamia, the examples of depicting children in civilian scenes and family in daily life are generally more than those depicted in warlike scenes related to prisoners of war, siege, and exile. *) The scenes of captives' processions were recognized in the Neo-Assyrian period in the first millennium $B C$. to reflect their strength and glory. *) The previous pictorial examples show that there are no fundamental differences in the representation of children, showing their ethnic roots through clothing or the like. Moreover, there is no difference in distinguishing their bodies and sizes. Children were represented smaller than the other persons in the figures. However, there is neither trait nor rule by which to know the nationality of the children represented. *) Children in captivity were represented under ten. The ages of the children of the prisoners, captives, and deportees in the Assyrian depictions included all phases of childhood. *) Children were dressed up. However, they appeared naked in many cases, fig $_{s}$. (1, 4, 5-a,b,c,d,e, 7-a,b, 8-a,b, 9, 10, 12-a,b). *) The nudity of children in Mesopotamian art can be explained by two possibilities. First, it was a traditional sign of childhood in other nations in the ancient near east, especially Egypt. Second, nudity gave the same meaning of psychological oppression and humiliation as the manner of captives' men, figs. (1, 5a). *) The Assyrian cared for the captives to be in good health before reaching the working destinations due to their economic value not for humanitarian reasons. So, in some representations, it can be seen that the carriages were available to transfer women and children, fig. (3-a,b, 5-a,b), or even donkeys for ridding, fig. (12-a,b). *) The exile and deportation punishment applied to all members of captives' families, women and children. Accordingly, children lost their freedom. The conditions of the deportee's families and children have been greatly affected by this policy. *) Some scenes attest to the suffering thirsty of the children while being transferred from their home to other places, fig. $(6,13)$.

\section{References}

[1] Boudin, S., (2011). Images of woman and child from the Bronze Age, reconsidering fertility, maternity and gender in the ancient world, Cambridge Univ. Press, UK.

[2] Rollin, S., (1984) Women and witchcraft in ancient Assyria, in: Cameron, A. \& Kurt, A. (eds.) Images of women in antiquity, Wayne State Univ. Press Australia, pp: 34-45.

[3] Mendelsohn, I., (1948). The family in ancient Near East, The Biblical Archaeologist, Vol. 11 (2), pp: 24-40.

[4] Mieroop, M., (1989). Women in the Economy of Sumer, in: Lesko, B, (ed.), Proc. of the Conf. Women's Earliest Record from Ancient Egypt and Western Asia, Brown Judaic Studies, Vol. 166, pp: 53-65.

[5] Saporetti, C., (1979). The status of woman in the middle Assyrian period, Sources and Monographs on the Ancient Near East, Vol. 2 (1), pp: 3-20.

[6] Marsman, H., (2003). Women in Ugarit and Israel: Their social and religious positions in the context of the ancient Near East, Oudtestamentische Studiën d. 49, Brill, London.

[7] Melville, S., (2004). Neo-Assyrian royal women and male identity: Status as a social tool, J. of the American Oriental Society, Vol. 124 (1), pp: 37-57. 
[8] Veenhof, K. \& Eidem, Jesper (2008). Mesopotamia: The oldAssyrian period, Academic Press. Fribourg, Switzerland

[9] Al-Hashem, T., (1433-1434 H). Al omomah waltofolah fi tashreaat belad al-rafeden 2500-500 B.C (Motherhood and childhood in the legislations of Mesopotamia, 2500-500 B.C.), MA, College of Arts, King Saud Univ., KSA.

[10] Matlub, Q., (2016). Fan al-zakhrafah al-Ashori fi alasr alhadith, derasah tarikhiyah tahlylya (The art of Assyria ornamentation in neo Assyrian period, a historical analytical study), J. of Higher Institute of Ancient Near East Civilizations, Vol. 2, pp: 854-879.

[11] Reade, J., (1979). Ideology and propaganda in Assyrian art, in: Larsen, M. (ed.), Mesopotamia 7: Power and Propaganda, a Symposium on Ancient Empires, Akademisk Forlag, Denmark, pp: 329-343

[12] Radner, K., (2010). Assyrian and Non-Assyrian kingship in the first millen-nium BC., in: Lanfranchi, G. \& Rollinger, R. (eds.) Concept of Kingship in Antiquity, History of Ancient Near East, Monographs, 11, Padova, pp: 25-34.

[13] Reade, J., (1976). Sargon's campaigns of 720, 716 and 715 B.C., evidence from the sculptures, J. of Near Eastern Studies, Vol. 35 (2), pp.95-104.

[14] Marcus, M., (1987). Geography as an organizing principle in the imperial art of Shalmaneser III, Iraq, Vol. 49, pp.77-90.

[15] Mohamed, D., (2015). Fan alnaksh ala alhajar fi asri alempiratoryah alhethyah wa alashoryah wama yoaserhoma fi misr alqadimah, derasah moqarnah (The art of some engraving in the Hittite and Assyrian empires and their contemporaries in ancient Egypt, a comparative study), Ph.D., Egyptology dept., Faculty of Archaeology, Cairo Univ., Egypt.

[16] Collins, P., (2006). The development of individual enemy, Source: Notes in the History of Art, Vol. 25 (3), pp: 1-8
[17] Albenda, P., (1970). An Assyrian relief depicting a nude captive in Wellesley college, J. of Near Eastern Studies, Vol. 29 (3), pp: 145-50.

[18] Parker, B., (2011). The construction and performance of kingship in the Neo-Assyrian Empire, J. of Anthropological Research, Vol. 67 (3), pp: 357-386.

[19] Poo, M. (2005). Enemies of civilization; Attitudes toward foreigners in Ancient Mesopotamia, Egypt and China, SUNY series in Chinese philosophy and culture, State Univ. of New York Press, USA.

[20] Saleh, M., (2010). Manazer alqetal wa hesar al modon fi fan alnaqsh alashory fi asr alemperatoryah maa moqaren-ateha pema fi fan alnaqsh almisry alqadim hata nehaya asr aldawlah alhadithhah (Representations of the fighting and siege of cities in Assyrian art in the NeoAssyrian empire with its comparison with that of ancient Egyptian scenes until the end of new kingdom), MA, Egyptology dept., Faculty of Archaeology, Cairo Univ., Egypt.

[21] Abdullatif, R., (2015). Derasah tahlyliah lemanhaj melok Misr wa Assur khelal alhamalat alasqaryiah fi gharb Asia (An analysis of approach of the kings of both Egypt and Assyria during the military campaigns in west Asia, MA, College of Women, Ain Shams Univ., Egypt.

[22] Oates, D. \& Oates J., (2001). Nimrud, an Assyrian imperial city revealed, British School of Archaeology of Iraq, London.

[23] Zaccagnini, C., (1995). War and famine at Emar, Orientalia, Vol. 64 (2), pp: 92-109.

[24] Saggs, H., (2001). The Nimrud letters, (Cuneiform texts from Nimrud 5), British School of Archaeology of Iraq, London.

[25] Parpola, S. \& Watanabe, K., (1988). New Assyrian treaties and loyalty oaths: State archives of Assyria, Vol. 2, Helsinki Univ. press, Finland. 
[26] Beckman, G., (2013). Foreigners in ancient near East, JAOS, Vol. 133 (2), pp: 203-216.

[27] El-Saady, H. (2001). Nabonidus in Arabia: A re-assessment, Adumatu, Vol. 4, pp: 7-20.

[28] Haugberg, K., (2016). Assyrian Foreign Policy in the Levant before Sennacherib, LAP Lambert Academic Pub., UK

[29] Shhylat, A. \& Alhamadani, A., (2011). Mukhtasar tarikh Aliraq (A brief history of Iraq), the ancient history of Iraq, Part- 4, Assyrian Period, (2500605 B.C.), Dar Al Kotob Alilmyiah, Beirut.

[30] Oded, B., (1979). Mass deportations and resettlements policy in NeoAssyrian empire, Dr. Ludwig Reichert Verlag Wiesbaden, Germany.

[31] Tsakanyan, R., (2018). Tiglath-Pileser III (745-727 B.C.) Mass depor-tations and resettlements policy in Assyria, $J$. of Armenian Studies, Vol.1, pp: 116136.

[32] Al-Alwsh I., (2010). Tabaqat almogtamaa alashory fi doua alnosos almesmaryiah (The levels of Assyrian society in the context of cuneiform texts), J. of Mosuliya Studies, Vol. 30, pp: 83-93.

[33] Salman, E., (2015). Seyasat altahjeer Alashory wa Albabyly wa dor Alfors fi doua asfar alahd alqadim, derasah tarykhyiah moqaranah, (The policy of Assyrian and Babylonian displacement of the Jews and the role of the Persians in the light of the book of the old tastement, a comparative historical study), unpublished $\mathrm{PhD}$, Hebrew Language dept., Faculty of Art, Ain Shams Univ., Egypt.

[34] Saleh, A., (2004). Al sharq aladna alqadim, Misr wa Aliraq, (The ancient near east, Egypt, and Iraq), Part 1, Al-Anglo Library Press), Cairo.

[35] Fuchs, A., (1994). Die Inschriften Sargon III, aus Korsabad, Universität Gottingen press, Cuvillier, Germany.

[36] Younger, K., (2002). Recent study on Sargon II, king of Assyria: Implica- tions for biblical studies, in: Chavalas, M. \& Younger, K. (eds.) Mesopotamia and the Bible, Sheffield Academic Press , London, pp: 288-329.

[37] Al-Aaraji, H. \& Al-Qaabi, M., (2017). Alasbab Alsyasyah leltahjeer Alqasry fi Aliraq Alqadim, (The political reasons of forced displacement in old Iraq), Lark for Philosophy, Linguistics and Social Sciences, Vol. 26, pp:1-12.

[38] Sarlo, D., (2013). The economics of mass deportations in neo-Assyrian period under Tiglath-Pileser III (744727 B.C), Near and Middle Eastern Civilisation dept., Univ. of Toronto, Italy.

[39] Nadali, D. (2014). The impact of war in civilian in the neo-Assyrian period, in: Nadali, D. \& Vidal, J. (eds.), The Other Face of the Battle: the Impact of War on Civilians in the Ancient Near East, Alter Orient und Altes Tastement, Band 413, UgaritVerlage, Göttingen, pp: 101-112.

[40] Belibtrea, E., (1991). Grisly Assyrian record of torture and death, Biblical Archaeology Society, Vol.17 (1), pp: 52-61.

[41] Bahrani, Z., (1993). The iconography of the nude in Mesopotamia: Essays on nudity in antiquity in memory of Otto Brendel, in: Schneider, L. (ed.) Notes in the History of Art, Vol.12 (2), pp: 12-19.

[42] El-Kilany, E. \& Kamal, S., (2012). The role and depiction of peasant children in Ancient Egypt, (Old and new kingdoms, a comparative study), Egyptian J. of Tourism Studies, Vol. 11 (1), pp: 12-25.

[43] Goelrt, O., (1993). Nudity in ancient Egypt, Notes in the History of Art, Vol. 12 (2), pp: 20-31.

[44] Mattiç, U. (2015). Children on the move $m s . w w r . w$ in the new kingdom procession scenes, in: Mynářová, J., Onderka, P. \& Pavúk, P., (eds.), Proc. of Int. Conf. There and Back AgainThe crossroads II, Charles Univ. press, Prague, pp: 373-388. 
[45] Barnett, R. \& Faulkner, M., (1962). The sculptures of Assur-nasir-apli II, 883-859 B.C: Tiglath-pileser III, 745-727 B.C. and Esarhaddon, 681669 B.C., from the central and southwest palaces at Nimrud Unknown Binding, Trustees of the British Museum, London.

[46] Bryne, R., (2003). Early Assyrian contacts with Arabs and impact on Levantine vessel tribute, Bulletin of the American Schools of Oriental Research, Vol. 331, pp: 11-25.

[47] Reade, J., (1998). Assyrian illustrations of Arabs, in: Phillip, C., Potts, D. \& Searight, S. (eds.), Arabia and its neighbours, essays on prehistorical and development: presented in honour of Beatrice de Cardi, Abiel II, New Research on the Arabian Peninsula, Turnhout pub., Belgium, pp: 221-232.

[48] Reade, J., (1983). Assyrian Palace Sculpture, British Museum Press, London.

[49] Ataç, M., (2010). The mythology of kingship in neo-Assyrian art, Cambridge Univ. Press, London.

[50] Orthmann, W., (1975). Der alte orient: Propyläen kunstgeshechichte 14, Verlag: Berlin.

[51] Al-Salibi, K., (1995). Altawrah gaat men gazerat Alarab (The bible came from Arabian peninsula), Arab Research Foundation Press, Beirut,

[52] Thomason, A., (2001). Representations of the north syrian landscape in neo-Assyrian art, Bulletin of the American Schools of Oriental Research, Vol. 323, pp: 63-96.

[53] Na'aman, N., (1993). Populatio changes in Palistine following Assyrian deportations, J. of Archaeology of Tel Aviv university, Vol. 20 (1), pp: 104-124.

[54] Collins, P., (2008). Assyrian Palace Sculpture, University of Texas Press, USA.

[55] Brinkman, J., (1973). Sennacherib's Babylonian problem: An interpretation, J. of Cuneiform Studies, Vol. 25 (2), pp: 89-95.
[56] Moortgat A., (1975). Alfan fi Aliraq alqadim, (The art in ancient Iraq), Dar Al Kotob Alarabiah, Baghdad.

[57] Lebmann, M. \& Tallis, N., Camurcuoglu D., et al. (2019). Esarhaddon in Egypt: An Assyrian-Egyptian battle scene on glazed tiles from Nimrud, in: Lehmann, M., Tallis, N., Camurcuoglu, D. et al. (eds.), British Museum Studies in Ancient Egypt and Sudan 25, pp: 1-100.

[58] Porada, E., (1989). Problems of late Assyrian relieves, in: Leonard, A. \& Williams, B., (eds.), Essays in Ancient Civilization: presented to Helene J. Kantor, The Oriental Institute of the Univ. of Chicago, Studies in Ancient Oriental Civilization 47, Univ. of Chicago press, pp: 233-248.

[59] Matthiae, P., (1999). Ninive, glanzvolle Hauptstadt Assyriens, Hermer, München.

[60] Cifarelli, M., (1998). Gesture and alterity in the art of Ashurbanipal of Assyria, The Art Bulletin, Vol. 80 (2), pp: 210-228.

[61] Luchenbill, D., (1927). The records of Assyrian and Babylonian, Vol.2, Historical records of Assyria from Sargon to the end, Univ. of Chicago press, Chicago.

[62] Nadali, D., (2007). Ashurbanipal against Elam, figurative patterns, and Architectural location of the Elamite war, Historiae, Vol. 4, pp: 57-91.

[63] Spalinger, A., (1974). Ashurbanipal and Egypt: A source study, J. of the American Oriental Society, Vol. 94 (3), pp: 316-328.

[64] Kahn, D. (2006). The Assyrian invasions of Egypt (6673-663B.C.) and the Final Expulsion of the Kushites, Studien zur Altägyptishen Kultur, Band.34, pp: 251-267.

[65] Abdullah, M., (2000). The foreign captives in ancient Egypt, PhD, Egyptology dept., Faculty of Archaeology, Cairo Univ., Egypt.

[66] Adamthwaite, M., (2001). Late Hittite Emar, the chronology, synchronisms and socio-political aspects of late 
Bronze age fortress town, Ancient Near Eastern Studies, Supl. Series 8, Peeters Pub., Louvain.

[67] Hallo, W., (1964). The road to Emar, J. of Cuneiform Studies, Vol.18 (3), pp: 57-88.

[68] Goetze, A., (1957). The Syrian town of Emar, Bulletin of the American Schools of Oriental Research, Vol. 147, pp: 22-27.

[69] Yamada, M., (2011). The second military conflict between Assyria and Hitti in the reign of TukultiNinurta I, Revue d'Archéologie Oriental, Vol. 105, pp: 199-220.

[70] Mango, E., Marzahn, J. \& Uehlinger, C., (2008). Könige am tigris, medien Assyrisher herrschaft, Universität Zurich, Swetzerland.
[71] Fares A., (2017). Asalyb taamol molok almamlakah Alashoryiah alhadithah (911-612 B.C.) Maa Asrahom men alhokam almotamareden, alasbab wa alnataeg, (Kings behaviors in the neo Assyrian period (911-612 B.C.) with their captives of rebellious rulers, reasons and results), Arabic Basra Arts Magazine, Vol. 79, pp: 176-216.

[72] Curtis, J. \& Reade, J., (2000). Art and empire, treasures from Assyrian in the British Museum, British Museum Press., London.

[73] Matthias, K., (2016). Relations of power in early neo-Assyrian state ideology, Studies in Ancient Near Eastern Record, De Gruyter, Berlin.

[74] Sager, H., (2008). Azamat Assur (The greatness of Assyria), Alaa El-Din Foundation Press, Damascus. 